\title{
Managing Bioplastics Business Innovation in Start Up Phase
}

\author{
Pornpun Theinsathid (1), Achara Chandrachai (2), \\ Suwimon Keeratipibul (3)
}

\begin{abstract}
Fostering innovation in a mature company can often seem like a swim upstream-the needs of the existing business often overwhelm attempts to create something new. Mature companies understand that to compete today they need to innovate. But finding sources of innovation while still paying attention to the current business can be a struggle. Open innovation has played an important role to drive the new business in 2 I th century. Academic research commercialization may be challenged by the faculty members' academic routines, institutional priorities, and faculty retention. In order to undertake applied research, university scientists must spend a certain amount of time each period to keep up with the latest scientific developments and absorb new ideas. Because almost all faculty members have teaching responsibilities, many of them fear that participation in the protection and commercialization of Intellectual Property Rights is time consuming.

There are lots of basic researches focuses on polylactic acid (PLA), the most promising bioplastics, however that is still far behind the commercialization step. The close innovation system may take longer time to achieve excellence in its technology under fierce competition environment. This study illuminates the complexities and challenges involved in managing innovation toward specific results. These challenges seem to result, in part, from the multidisciplinary nature of R\&D work, it associated with risks, uncertainty and non-linear processes. One of the finding in this study is that many of the factors that drive innovative bioplastic industry are derived in collaboration with technology push and demand pull. The study's findings contribute to our understanding of consumer attitudes towards 'Green' products such as bioplastics. Most critical in this respect is whether such products make economic sense for a company. This study may provide some guidelines to support development of a concrete direction for PLA under open innovation atmosphere.
\end{abstract}

Keywords: Bioplastics, Open Innovation, Technology transfer, Polylactic acid value chain, Biobased Economy.

(I) Graduate School Interdisciplinary Program, Technopreneurship and Innovation Management, Chulalongkorn University, Bangkok, Thailand. E-mail: p.theinsathid@purac.com

(2) Department of Commerce, Faculty of Commerce and Accountancy, Chulalongkorn University, Bangkok, Thailand

(3) Department of Food Technology, Faculty of Science, Chulalongkorn University, Bangkok, Thailand 


\section{I.The role of managing innovation in start up of bioplastics business}

Thailand is an agricultural country, and is a major producer of economic crops such as tapioca and sugar. Sugar production in Thailand has grown continuously for more than 20 years, to the extent that today the country has become one of the world's largest sugar exporters. The industry is one of the country's leading industrial sectors, and plays an important role in the country's economic and social development, generating more than 50 billion baht annually from exports and domestic sales.

Successful of converting feedstock commodities to value added product such as polylactic acid (PLA) would bring significant benefit to the national economy, and trigger an influx of more advanced technologies to stimulate further advances e.g. in process technologies. This study focuses on one category of bioplastic: Polylactic acid (PLA). Although at present only one company worldwide has succeeded in commercializing PLA production, Thailand has sufficient feedstock resources and raw material support to move forward with biobased economy. But dealing bioplastics business and introducing the environmental dimension in a company strategy is however a complex challenges. In particular, four major problems explain the complexity of set up bioplastics business and improving environmental efficiency

- the multi-dimensional nature of environmental management. Implementing 'green' innovations usually implies investing in many different technologies that lie beyond the company's traditional technological scope (I)

- $\quad$ the broad scope of environmental programmes. In fact, these programmes have systemic impacts on the whole organization, requiring the involvement of all the organizational units of the corporate management system, such as Marketing, R\&D, Manufacturing, Purchasing, Logistics, and Quality Management. Moreover, bioplastics programmes entail actions on the whole supply chain, involving suppliers, retailers, customers, final users, and other non-traditional stakeholders (2-3)

- $\quad$ the significant financial commitment associated with the introduction of bioplastics programmes (4)

- $\quad$ the diversification of change drivers. Environmental pressures may vary considerably according to the industry and geographical location of a firm's activity (5)

Given this scenario, it must be considered that 'green' innovation may be managed implicitly, i.e. the environment is considered as a secondary factor to be examined indirectly only when it affects other strategic variables of a company, or explicitly, i.e. the environment is considered as a major strategic challenge and its various implications are system examined. The first approach may lead to a reactive strategic attitude. This is a major problem when there is a considerable delay between the implementation of an environmental program and the improvement of the environmental performance, thus implying that a company may lag behind competitors for a long time frame (I).

Moreover, implicit and reactive strategies lead to continuous incremental changes in operations and/or products whereas, as said above, environmental programs entail systemic and consistent changes. As a consequence, implicit management of environmental issues often results in several uncorrelated elementary actions that as a whole call for high sunk costs. In contrast, explicit environmental management is linked to radical innovations, whose adoption requires significant financial commitment at the development phase. However, when effectively designed, it allows managers to better control the change process, save sunk costs and, eventually, improve a company's profitability (6). Moreover, explicit management is necessary when environmental issues are exploited to gain competitive advantages (7). Specifically, within countries where the market is characterised by a high environmental awareness and regulations set binding environment related standards, the introduction of product and/or process 'green' innovations may lead a company to improve its market share and/or reduce economical efforts associated with environmental management (taxation, waste disposal, pollution control, etc.)

This paper contributes to this debate, investigating whether 'green' product innovation may occur and may have strategic implications. Specifically, the objective of the paper is to improve the understanding of nonlinear aspects of innovation processes by qualitatively studying (i) The importance and value of the original idea that the studied companies were based upon in their start-up phase and (ii) The role of customer involvement in these processes and (iii) to suggest a framework to support venture in the analysis of the drivers of green product innovation and in the choice of a proper R\&D strategy that explicitly accounts for the bioplastics of product technologies. The major findings were analyzed by using SWOT analysis. The study aims to gain an insight into the possibility to set up bioplastics business.

\section{Literature Review}

Sugar is currently used as a raw material for lactic acid production. In Thailand, the world's largest lactic acid producer, PURAC, (The Netherlands-based company) opened a state of the art lactic acid production facility in Rayong, Thailand on Jan 2008. The new facility will reinforce PURAC's position as the world's largest manufacturer of natural lactic acid, lactic acid 
derivatives and lactides, using sugar as the key raw material (Fig. 2). Apart from bioplastics, lactic acid and its derivatives have a wide range of applications in many different industries, including food, pharmaceuticals, medical, cosmetics, animal feed, technical \& chemical applications (8-10). The basic building block of PLA is lactic acid, which can be produced by carbohydrate fer- mentation or sugar fermentation. Currently, the majority of lactic acid production is based on the sugar fermentation route. One of the main drivers for the recent expanded use of PLA is an increasing environmental concern, and the unsustainability of fossil-based plastics produced from non-renewable resources.

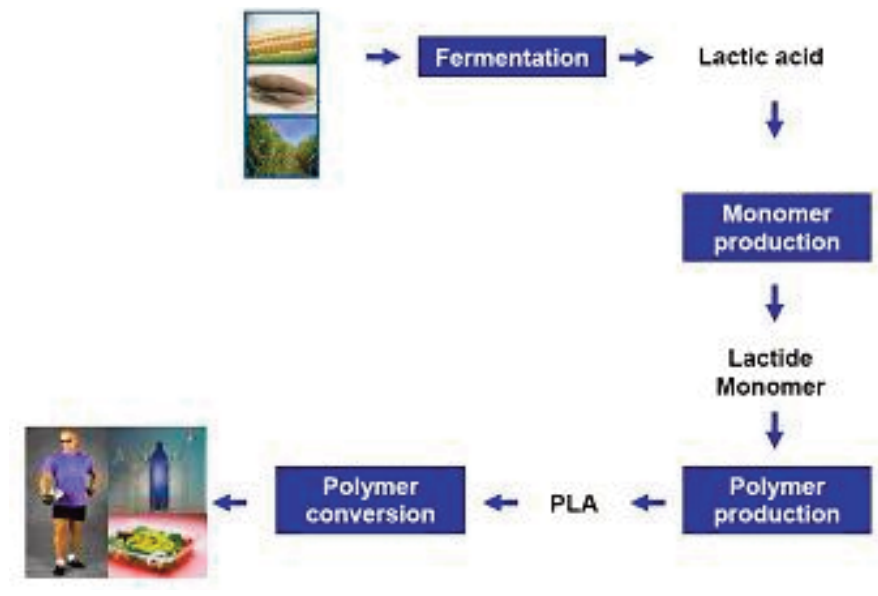

Figure 2: Polylactic acid value chain

\section{Biobased plastics}

As fossil reserves decline and the cost of petrochemicals increases, industry must source renewable resources if its manufacture is to become sustainable. Plants provide cheap, renewable factories for the production of industrial raw materials and chemicals of value to a wide range of non-food industrial sectors. In the coming years, economics, legislation and environmental issues will all drive policy to support sustainable growth across the European Union and globally. Polylactic acid is a biobased renewable plastic, whose potential has been increasingly studied for a large number of mass-production applications such as packaging, paper coating, fibers, films, and other disposable articles, as well as in biomedical applications, such as resorbable surgical sutures, implants, and controlled drug delivery devices (II). These types of application sectors bring highly specific requirements to the polymers and monomers, which must be fulfilled before the respective application can be successfully launched. These polymers need to be biodegradable and non-toxic or, in the biomedical applications, bioresorbable and biocompatible. On the other hand, polymers need to have good chemical, mechanical, thermal and rheological properties. In addition, in the packaging sector, the raw materials should be annually renewable and the end products should be compostable to reduce the use of fossil resources. Furthermore, the raw materials and the end products should be reached affordable price and the production processes on an industrial scale should be efficient, environmentally friendly and economically competitive.Additional benefits for packaging ap- plications are good heat seal ability and process ability with standard plastic equipment. Recent advances in the production process of polylactic acid, together with improvements in the material properties, have also opened up a promising market outlook in the sector of fibers and non woven, films, thermoformed and injection molded articles (12-14). The use of polymers in packaging, and the corresponding waste materials produced, results in considerable environmental impact. The removal of plastics from packaging is not a viable option. Mechanical recycling of polymers and energy recovery by incineration is primary strategies for reducing plastic waste. Despite the efforts to recycle used plastics, recycling is neither practical nor economical for certain applications, such as waste bags, agricultural mulch films, or food packaging. In this kind of application, the composting of items produced from biodegradable polymers has advantages compared to other types of municipal waste management.

Nowadays, commercial bioplastics in the market are mainly copolymers. The marketing of bioplastic products has always been driven by their performance, and so specific performance characteristics are achieved by blending with other materials. European Bioplastics estimates that in 2007, all bioplastics applications comprised approximately 75,000-100,000 tons of the total 48 million ton European plastics market.Annual growth is considerably higher than 20\% (Fig.3). Experts regard a technical application potential of 5- 10\% of the total plastics market as realistic (15). 


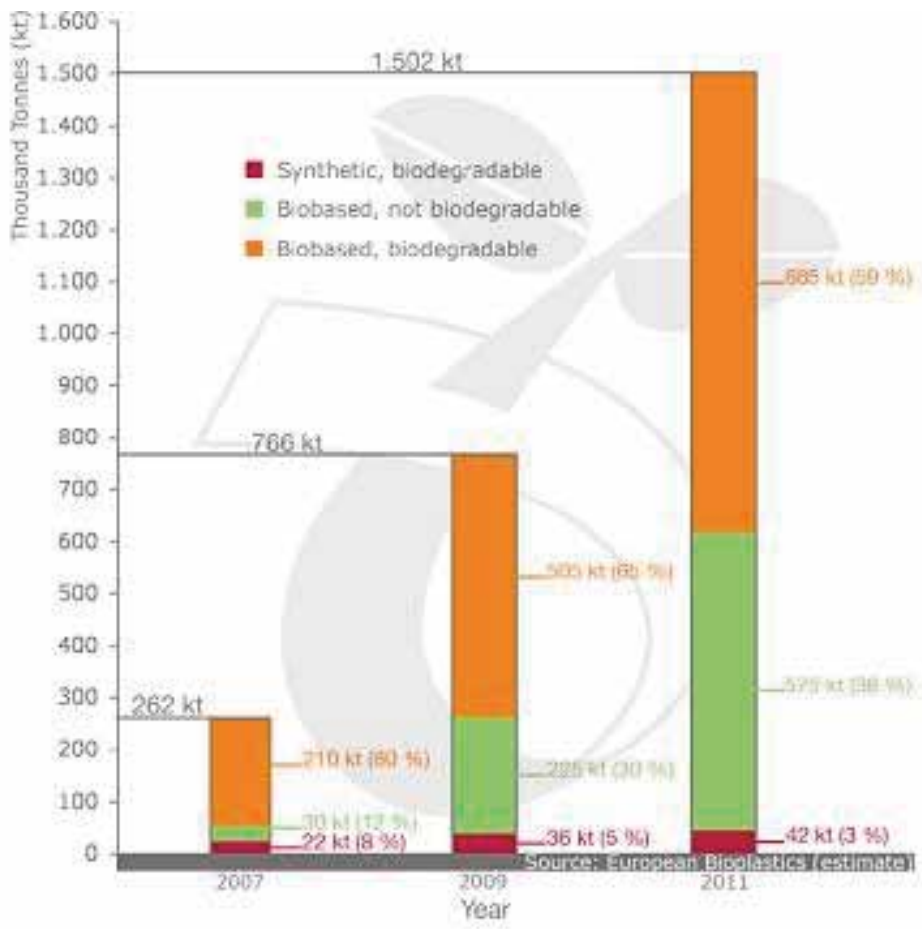

Figure 3:Annual bioplastics production capacity 2007-20 I I

\section{Methodology}

\section{Research methodologies}

The lead user techniques by Von Hippel were used in this research (16-18). The study employed in depth interviews with top lead users/early adopters of senior government officers, research institutes and senior position from private companies with a direct role in development of the bioplastics business in Thailand. Total seven interviewees were selected as representative of lead users in their respective sectors. The research methodology is shown in figure 4.

Lead users are defined as users who

(i) Face needs that will be general in a marketplace, but they face them months or years before the bulk of that marketplace encounters them, and

(ii) Are positioned to benefit significantly by obtaining a solution to those needs

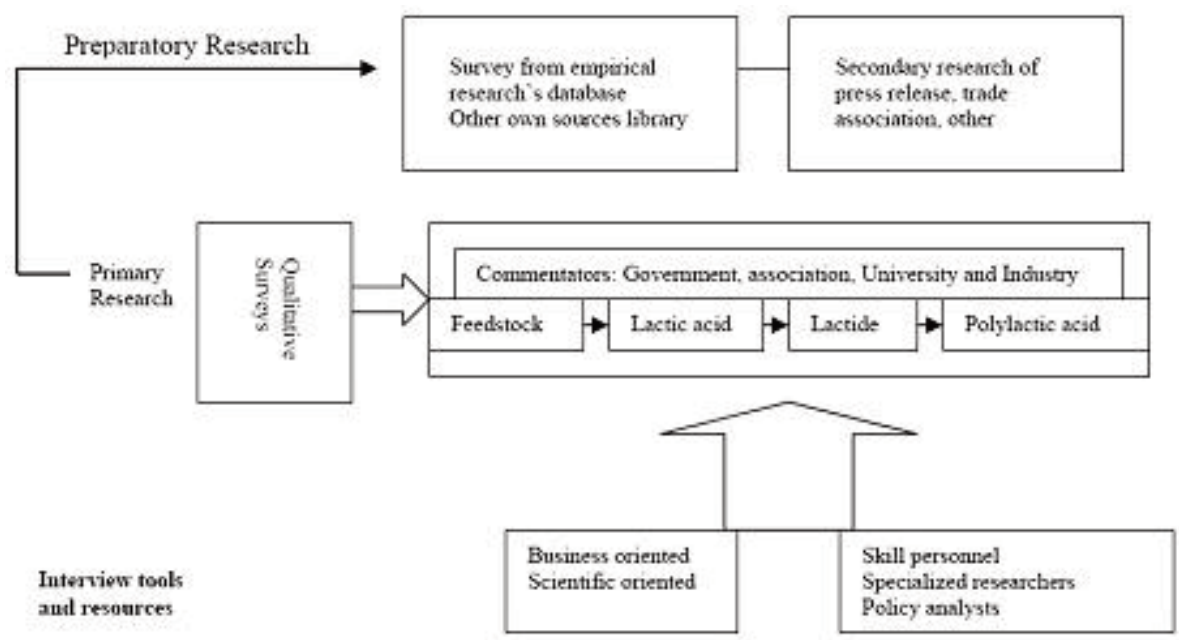

Figure 4: Research Methodology 
The interviewer introduced themselves, stated the general aims of the study. When possible, the interviews were tape-recorded, but where interviewees objected, detailed noted were taken during the interviews. All issues, including those that were brought up by the informants, were pursued through follow up questions until interviewer and informant felt they had been dealt with adequately. The interviews lasted for 60-90 minutes. The interviewer summarized the main ideas contained in the answers provided, asked for any final comments or questions, thanked the subject for his or her participation and closed the interview.

This research study was focused on upstream side of the whole value chain of bioplastics as indicated in figure 5 . In depth in-

terviews were conducted with three main sectors, which have main contributions in the upstream, consisting of government, manufacturing and universities and research institutes. Seven interviewees were selected as representative of lead users in their respective sectors.

No. of interviewees

3

2

2
Sector

Government

University/Research institute

Manufacturing

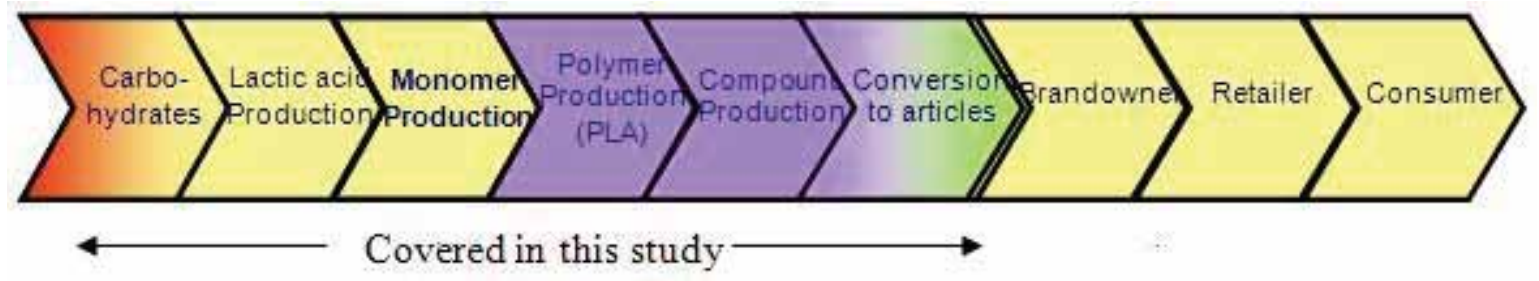

Figure 5: The whole bioplastic value chain

\section{Results and Discussion}

The finding from a survey of empirical literature researches were analyzed and adapted to align with Thailand context.

\section{Internal analysis:}

\section{Strength:}

- Bioplastics is an alternative source of petroleum based

- Being set up standard and certification body according to ISO 17088 and EN 13432. This program support by National Innovation Agency (NIA), National Metal and Materials Technology Center (MTEC), Thai Biopalstic Association Industry(TBIA) and Chulalongkorn University

- High awareness of global warming issue

- Life Assessment Cycle indicated less carbon dioxide release when compare with petroleum based plastics.

- All the parties emphasized the need to promote environmental responsibility

- There is a need to share the knowledge of each industry in order to understand PLA properties for specific application.
- Researchers are working on PLA polymerization and mechanical property improvement.

\section{Weaknesses:}

- Environmental policy needed to be seriously implemented by government to sustainable growth of bioplastics business.

- Need to quantify amount of CO2 mitigation achieved by using respective bioplastics products.

- High market awareness, but not real effect to the industry due to cost of product.

- High cost of the finished product when compare with traditional plastics.

- Mechanical property of PLA still presents constraints to final applications, particularly its limited heat resistance. Co polymerization or blending is required to achieve performance for specific application.

- Need to close the gap between research advances and commercialized products

- Economical question 
- There is a need to educate market about bioplastics and its benefit

- Technical and technology know how on PLA production

\section{External analysis:}

\section{Opportunity}

- Strong environmental movements in the EU, Japan and USconcern about sustainability, global climate change and waste disposal options have created a market opportunity for natural compostable bioplastics.

- EU-wide policy support

- Growing market supported lead by EU, USA and Japan.

- Encourage through EU directive DIN I3432

- Increase petroleum cost and limited fossil resource for the future.

- High demand for export products

- Global warming concern, and 2 I st century is bio-based eco- nomy.

\section{Threats}

- Limited raw material supplier

- Low user awareness of renewable feedstock derived products and their benefits

- Performance of PLA-based products especially regards to mechanical properties and heat resistance properties.

Lead users were asked to rank the most important factors as drivers for the bioplastics industry in Thailand. The top three important factors reported were packaging law, government policy and costs. Then, the lead users were asked to rank the most important factors to maximize the success of bioplastics industry in the next five years. The top three factors were chosen are public policy, technology and open innovation through academic-industry relationship. The last questions before ending interview, the key stakeholders were asked for their opinion about the most interesting end applications for polylactic acid (PLA) to focus on as indicated on Table 2. The top three interested from all stakeholders's opinion are food packaging, injection moulding and automotive components.

\begin{tabular}{|l|l|}
\hline $\begin{array}{l}\text { The most interesting end } \\
\text { applications for Polylactic } \\
\text { acid (PLA) to focus on, } \\
\text { (Thailand context) }\end{array}$ & $\begin{array}{l}\text { Ranking (the most impor- } \\
\text { tant ranking no. I) }\end{array}$ \\
\hline Electronic applicances & \\
Automotive components & \\
Fibers/Textiles & \\
Injection molding & \\
Food packaging film & \\
Food packaging tray & \\
Agricultural film & \\
Other - please state: & \\
\hline
\end{tabular}

Table 2: Lead users opinion on major applications for Polylactic acid

The in-depth interview clearly indicated that there are several bioplastics projects on going in their respective sectors under open innovation asmosphere (19-20). Based on the PLA project, it has been observed that government research and industrial research focus on different aspects of bioplastics feasibility. Government research tends to focus more on basic research on how to produce polylactic acid and follow by studying modification of PLA to improve mechanical properties. Meanwhile, the industrial sector prioritizes technology transfer and licensing opportunities (Table3). However, there are limited on academic - industry - supplier linkages for bioplastics projects study in Thailand., offering important synergies for developing Thailand's bioplastics industry. 


\begin{tabular}{|l|l|l|}
\hline $\begin{array}{c}\text { Bioplastics prod- } \\
\text { uct }\end{array}$ & $\begin{array}{c}\text { Universities and research } \\
\text { institute }\end{array}$ & \multicolumn{1}{|c|}{ Industrial sector } \\
\hline Starch based & $\begin{array}{l}\text { Blending starch with PLA and } \\
\text { other polymers for mechani- } \\
\text { cal properties improvement. }\end{array}$ & $\begin{array}{l}\text { Blending compound with } \\
\text { starch, PLA and others poly- } \\
\text { mers to improve properties }\end{array}$ \\
\hline Polylactic Acid (PLA) & $\begin{array}{l}\text { Focus on production of lactic } \\
\text { acid from sugar, tapioca starch. } \\
\text { Also cover to polymerization } \\
\text { of lactic acid to PLA, modifi- } \\
\text { cation of PLA to improve me- } \\
\text { chanical properties }\end{array}$ & $\begin{array}{l}\text { Mainly focus on PLA technol- } \\
\text { ogy licensing rather than } \\
\text { from lactic acid to PLA }\end{array}$ \\
\hline $\begin{array}{l}\text { Poly-hydroxy alka- } \\
\text { noates (PHA) }\end{array}$ & $\begin{array}{l}\text { Focus on screening of mi- } \\
\text { croorganism, optimization of } \\
\text { fermentation process and } \\
\text { property assessment }\end{array}$ & Study properties assessment \\
\hline
\end{tabular}

Table 3: Biodegradable main researches focus in Thailand

The different prospective of technology, economic, policy and market among key stake holders were summarized in Table 5 . The major finding found that the government and private sectors need to prepare the sustainable system for serving bioplastics industry in the future. There are requirements such as certify body system, life cycle assessment and the result from Table 5 clearly indicated that price and mechanical properties are main barriers to move forward PLA base plastic for the present time. In the rapidly and radically evolving environment of recent decades, innovation is no longer a matter of profitability but it has become a critical survival factor for companies. Yet, innovation is expensive and risky, and the high rate of market failures remains an unsolved problem. However, in this qualitative research with lead users and key stakeholders in Thailand, respondents were convinced that the new innovative business in the country where agricultural products are a main feedstock, show promising potential.

PLA is a relatively new material. PP, PS, and PET are commodities produced in large-scale facilities that have been optimized over many years of commercialization. In comparison, PLA certainly still is at infancy period of market development and process optimization. Materials made from PLA will not replace conventional plastic anytime soon. In the coming years production of PLA may increase while production of conventional plastics could show a slight decline. Using PLA has shown prom- ising potential to mitigate GHG emissions. However, further research is needed to compare petroleum-based plastics with bioplastics on the basis of cost and non renewable energy consumption from the beginning of the production process until end of life - "cradle to grave".

Some experts claimed that the main barrier of biopolymers is not technical, but economic. In the area of plastic, function and cost are critical criteria. Accordingly, renewable materials such as starches, cellulose, and fibres that could be used in PLA blends to reduce costs without significantly degrading performance would be of great commercial interest. Over the past years the price ratio of agricultural materials: crude oil has declined significantly. This price ratio decline seems likely to continue and narrow the gap between the prices of synthetic and bioplastic resins. Bioplastics should be developed energetically, but within the context of appropriate environmental policies, packaging law and using approaches that are both sustainable and cost-effective. It is very important to be able to collaborate with other industries to explore product and market possibilities. 


\begin{tabular}{|c|c|c|}
\hline \multicolumn{3}{|l|}{ Primary factors } \\
\hline Price & $\begin{array}{l}\text { Reduction of materials, re- } \\
\text { sources, energy consump- } \\
\text { tion, water use, operation } \\
\text { costs } \\
\text { Efficient employment }\end{array}$ & $\begin{array}{l}\text { Savings on production and } \\
\text { product costs } \\
\text { Reduced product price } \\
\text { Increased price elasticity }\end{array}$ \\
\hline Product Quality & $\begin{array}{l}\text { Process optimization } \\
\text { Improving/maintaining } \\
\text { input material quality } \\
\text { Life-Cycle Assessment }\end{array}$ & $\begin{array}{l}\text { Efficient utilization of } \\
\text { means of production } \\
\text { Enhancement of product } \\
\text { quality } \\
\text { Improvement of reputa- } \\
\text { tion }\end{array}$ \\
\hline \multicolumn{3}{|l|}{ Secondary factors } \\
\hline $\begin{array}{l}\text { Product perform- } \\
\text { ance }\end{array}$ & $\begin{array}{l}\text { Improvement of introduc- } \\
\text { tion of R\&D, product inno- } \\
\text { vation and flexibility } \\
\text { management, learning or- } \\
\text { ganization and team ori- } \\
\text { entation }\end{array}$ & $\begin{array}{l}\text { Product and process inno- } \\
\text { vation } \\
\text { Product improvement } \\
\text { Improved marketing } \\
\text { Improved internal profes- } \\
\text { sionalism and flexibility }\end{array}$ \\
\hline $\begin{array}{l}\text { Business perform- } \\
\text { ance, reputation }\end{array}$ & $\begin{array}{l}\text { Environmental Policy } \\
\text { E } \mathrm{n} \text { v i } \mathrm{r} \text { o } \mathrm{n} \text { m e } \mathrm{n} \mathrm{t} \text { a I } \\
\text { Management systems and } \\
\text { certifications } \\
\text { Risk management } \\
\text { Product Labels on environ- } \\
\text { ment and quality } \\
\text { Compliance with interna- } \\
\text { tional standards } \\
\text { Marketing }\end{array}$ & $\begin{array}{l}\text { Improved reputation } \\
\text { Proved enhanced social } \\
\text { and environmental com- } \\
\text { mitment } \\
\text { Consumer/customer ori- } \\
\text { entation } \\
\text { Increased shareholder } \\
\text { value }\end{array}$ \\
\hline
\end{tabular}

Table 4: Bioplastics efficiency and Competitiveness

A widespread view within the renewable community is that consumers, both within business and among the wider public, are unaware of the existence of feedstock-derived plastics or the environmental and performance advantages they offer. Materials based on renewable resources are often assumed to be of lower quality or inferior performance. This negative or non-existent consumer perception has a significant impact on the market for renewable materials.

The above excurse and Table 4 illustrate that much more than efficient production methods with subsequent savings and im- provement of environmental and economic performance are required to enable a business to keep hold on the market. Through savings and improved environmental performance, a business only attained a certain potential of a competitive advantage through an increased profit margin. This potential needs to be turned into real competitiveness. For that reason, companies need to develop strategies focusing at least on the technical, economic, management and public awareness subsets of green business measures to navigate through the chain of building competitiveness. 
J.Technol. Manag. Innov. 2009, Volume 4, Issue I

\begin{tabular}{|c|c|c|c|c|}
\hline & Technology & Economics & Policy & Market \\
\hline Policy maker & $\begin{array}{l}\text { Should indicate how } \\
\text { much carbon dioxide } \\
\text { is able to reduce by } \\
\text { using respective bio- } \\
\text { plastics product. }\end{array}$ & $\begin{array}{l}\text { Renewable feed stocks } \\
\text { in Thailand such as } \\
\text { sugar and tapioca. }\end{array}$ & $\begin{array}{l}\text { - Drive bioplastic busi- } \\
\text { ness through } \\
\text { "Biodegradable plastic } \\
\text { national road map", } \\
\text { which approved by Thai } \\
\text { cabinet on July } 2008 \\
\text { - Board of Investment- } \\
\text { BOI (Thailand) has } \\
\text { planned to put invest- } \\
\text { ment incentives and ex- } \\
\text { plore opportunities of } \\
\text { bioplastics business in } \\
\text { Thailand. }\end{array}$ & $\begin{array}{l}\text { - Price sensitive } \\
\text { - Uncompetitive prices. } \\
\text { No local raw material } \\
\text { available. } \\
\text { - Lack of serious envi- } \\
\text { ronmental law enforce- } \\
\text { ment }\end{array}$ \\
\hline Researcher & $\begin{array}{l}\text { Researchers are } \\
\text { working on PLA poly- } \\
\text { merization and me- } \\
\text { chanical property } \\
\text { improvement. }\end{array}$ & $\begin{array}{l}\text { World largest lactic } \\
\text { acid plant in Thailand } \\
\text { with use as raw mate- } \\
\text { rial for polylactic acid } \\
\text { production. }\end{array}$ & $\begin{array}{l}\text { Set up standard and cer- } \\
\text { tify body according to } \\
\text { ISOI } 7088 \text { and ENI } 3432\end{array}$ & Price sensitive \\
\hline Manufacturing & $\begin{array}{l}\text { Plastic converter in- } \\
\text { dustry in Thailand is } \\
\text { hand on experience } \\
\text { and existing machin- } \\
\text { ery equipments are } \\
\text { suitable or only small } \\
\text { adjustment needed to } \\
\text { apply with biodegrad- } \\
\text { able plastics }\end{array}$ & $\begin{array}{l}\text { Price uncompetitive. } \\
\text { Limited PLA producer } \\
\text { and no local producer } \\
\text { available. } \\
\text { High cost of end prod- } \\
\text { uct, when compare } \\
\text { with conventional plas- } \\
\text { tics. }\end{array}$ & $\begin{array}{l}\text { Import tax for polylactic } \\
\text { acid is still not category } \\
\text { separately. It is go with } \\
\text { family of aliphatic poly- } \\
\text { esters }\end{array}$ & $\begin{array}{l}\text { - Lot of enquiry from } \\
\text { customers, but price is } \\
\text { a high barrier } \\
\text { - Need to improve } \\
\text { heat resistant and me- } \\
\text { chanical property to } \\
\text { serve the market de- } \\
\text { mand } \\
\text { - Lack of customer } \\
\text { orientation }\end{array}$ \\
\hline
\end{tabular}

Table 5: Major finding from the primary qualitative research

Technology push and Demand Pull in Bioplastics industry

From this exploratory research on early phase of bioplastics industry emphasis recently found that the linear technologypush and market-pull models have in recent years received a lot of criticism among researchers and practitioners for the absence of feedback loops between downstream and upstream elements within the process chain. The later models include these feedback systems and emphasize the interactive nature of the innovation processes.

This bioplastics business limited to small start-up companies and entrepreneurs generally do not have access to extensive $R \& D$ resources in which knowledge can be created, it is especially important for them to have a high knowledge absorption capacity in order to improve their innovation capacity. The absorption capacity can be improved by engagement in network activities by the exchange of knowledge with external sources, such as customers, suppliers, consultants and other companies (21). Large companies have their own existing network and channel to access above information.

Models have been created which describe different degrees and roles of customer involvement in innovation processes. For example, von Hippel (22) introduced the Customer Active Paradigm (CAP). In the CAP, customers are taking an active role as idea generators and problem solvers. This is in contrast with the more traditional Manufacturer Active Paradigm (MAP), in which manufacturers are taking an active role as innovators, while customers are more passive. Later, the CAP was developed into the concept of lead users, which are considered especially favourable to collaborate with in innovative projects (23). 
Further empirical studies have shown that lead plastic manufacturer customers are engaged in innovation activities themselves by either developing or modifying the product. In a study focused on the upstream customers, it was shown that this was largely due to the heterogeneity of their customers' needs. Many customers operate in niche markets and are willing to invest in customizing the product according to their special needs.

Understanding customer needs has shown to be critical in order to successfully commercialize inventions. Interaction with customers can help the company to gain information about market needs and new technological advancements. In this study context, collaboration among industry, government and academic during the product development process, especially in the early and late phases, has shown to have a positive impact on product success. In order to create the most value for the customers, it is essential for the company to understand the customer needs by an active exchange of knowledge. One kind of customer involvement is termed co-development, in which the producing company and the customers work closely through the entire product development process, exchanging knowledge, ideas and expertise (24).

\section{Conclusions}

Even a gap between research institute, university research and private sector is shown. This study finding indicated high po- tential for Thailand to establish bioplastics business. This is the tremendous of raw material supply, government support and technology advantage. This is in line with PURAC- a Dutch based company in Thailand to accelerated Polylactic acid - bioplastics business in Thailand. This is definitely increase country competitiveness in term of value added to feedstock, sugar or cassava, technology transfer and bring new business to the country. The model purposes (Fig.6) show that to success in bioplastics business, need to well establish linkage between industry-government-academia research consortiums, which is important fundamental element. As mentioned above, the main barrier for PLA is mechanical property. PURAC has successful produce D-Lactide in order to make sterocomplex PLA. The stereo complex PLA can overcome the weakness mechanical point of PLA and increase heat deflection temperature. However, to success in PLA business there is a clear need of market entry strategy and specific product since at the moment PLA is not competitive enough with commodity plastics. Therefore, the entrant to the business, should focus on value added or high end PLA product application plus collaboration with research consortium group for bioplastics. Nevertheless, qualitative primary research from lead users, who play important role in setting up bioplastics/green industry in Thailand, indicate possible ways to overcome fierce competition in the market as summarize here:

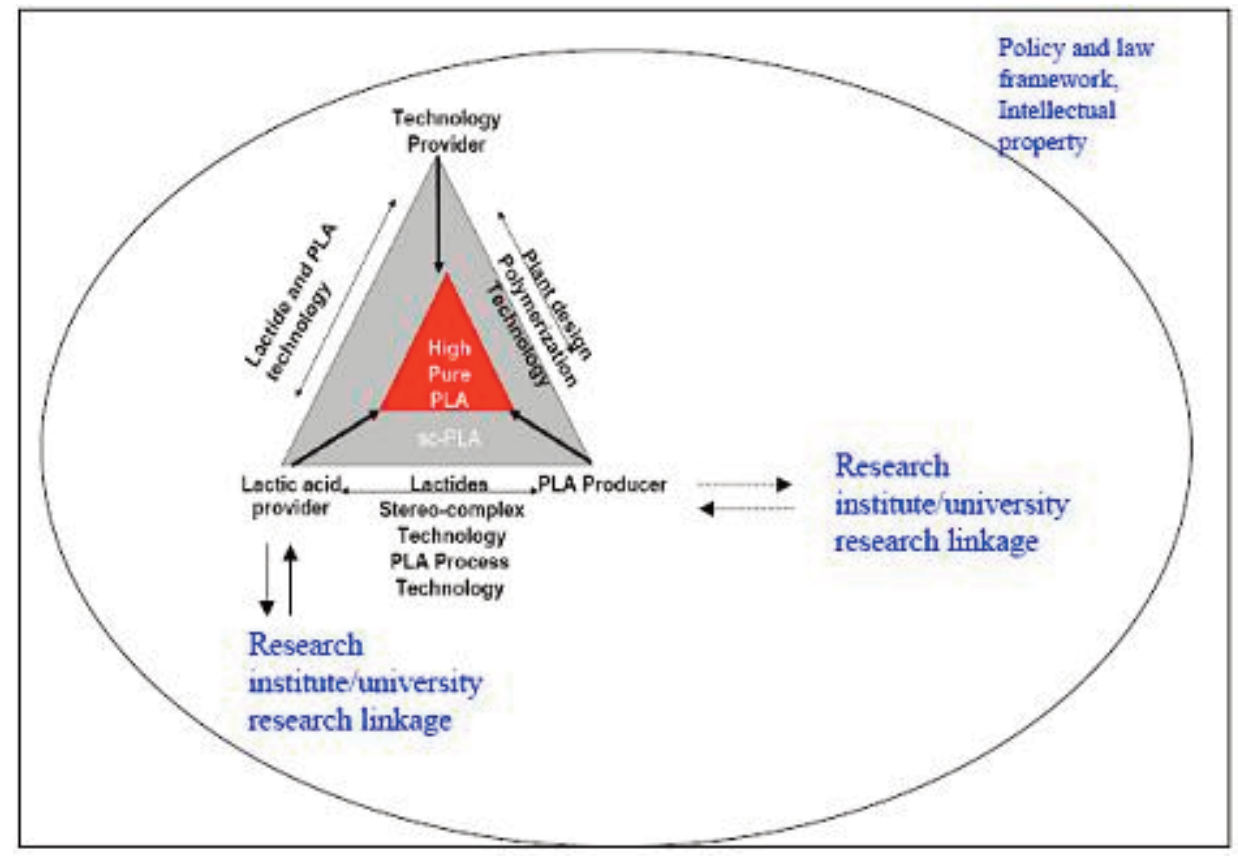

Figure 6: Open innovation model for bioplastic (PLA) succession (adapted from Purac) 
To increase sales of environmentally friendly products, companies must remove these five barriers-lack of awareness, negative perceptions, distrust, high prices, and low availability. Companies first need to figure out which customers would probably want which products and then examine how people in each market segment make their purchasing decisions. No matter which barriers prove most important for given product, industry, and region, businesses must ultimately address barriers in all areas before consumers will change their behaviour. In other words, companies have to move customers through every stage of the purchase process-from becoming aware of eco-friendly products to finding them. Consumers will not think better of green products until companies make them equal to, or better than, their conventional alternatives. It's no surprise: most people value performance, reliability, and durability much more than ecological soundness.

Green chemistry patent are an one of indicator of environmental innovation and R\&D.Trend in patenting activity are consistent with other empirical studies that point to the importance of regulatory pressure and consumer opinion for encouraging continued green innovation (25) Suggested that to boost bioplastics business resulting from environmental regulation, which can help bioplastics to meet new regulatory constrains at lower cost.

Businesses by themselves could not lead consumers from intentions to actions, the government and nonprofits must often participate actively to achieve long-lasting changes in consumer behavior. Nevertheless, businesses should play a leading role in the green movement in order to shape their market opportunities and manage potential regulation of their industries. Understand the marketing issues and opportunities associated with identifying a niche and building a business plan to address it. Above of this activities would not success only by technology push, but required combination skill of scientific and business orientation in the same time. The correct balance will need to be struck between industry and government 'push' (eg choice editing) and consumer 'pull' (demand for more sustainable products). Question is how far activities intended to enhance the competitiveness through bioplastics industry and considered all necessary steps within the implementation procedure in sub sectors and/or companies.

\section{References}

I. GUPTA, M.C. (1995) Environmental management and its impact on the operations function. International Journal of Operations and production Management, I5, 8, 34-5I

2. ROOME, N. (1992) Developing Environmental Management Strategies. Business Strategy and the Environment, I, Part I, I I24.

3. STEGER, U. (1996) Managerial issues in closing the loop. Business Strategy and the Environment, 5, 252- 268.

4. WALLEY, N. and Whitehead, B. (1994) It's not easy being green. Harvard Business Review. May-June, 72, 46-52.

5.AZZONE, G., Beret, U. and Noci, G. (1997) Developing business policies for environmental management. Long Range Planning, 30, 4, 562-57I.

6. AZZONE, G. and Noci, G. (1998) Seeing the environment as a source of change. Journal of Organizational Change Management, II, 8, 94-III.

7. SHRIVASTAVA, P. (1995a) Environmental technologies and competitive advantage. Strategic Management Journal, 16, I83200.

8. GARLOTTA D., (2002) A literature review of Polylactic acid, Journal of Polymer and the Environment, 9, pp.63-84.

9. SEYDIM AC., et al, (2006) Effects of Rosemary Extract and Sodium Lactate on Quality of Vacuum- packaged Ground Ostrich Meat, Journal of Food Science, 7I, pp7I-76.

10. OU SHIYI., et al, (2008) Reduction of acrylamide formation by selected agents in fried potato crisps on industrial scale, Innovative Food Science and Emerging Technologies, 9, pp. I I6- I 2 I.

II. SOPPIMATH K.S, et al, (200I) Biodegradable polymeric naoparticles as drug delivery devices, Journal of controlled release, 70, ppl-20.

12. SODERGARD A and Stolt M. (2002) Properties of lactic acid based polymers and their correlation with composition, Progress in Polymer Science, 27, pp I I 23-I I 63. 
13. STEFANIA Q., Loredana V., (2002) Antimicrobial food packaging in meat industry, Meat Science, 62, pp 373-380.

14. VALENTINA S., (2008) Biodegradable polymers for food packaging: a review, Trend in Food Science \& Technology, pp I- I0.

15. LORENZ P., and Zinke H., (2005) White biotechnology: differences in US and EU approaches? Trends in Biotechnology, 23, Pp. 570-574.

16.VINKA E.T.H., et al, (2003) Applications of life cycle assessment to NatureWorksTM polylactide (PLA) production, Polymer Degradation and Stability, 80, pp.403-419.

17. URBAN, Glen L., and Eric von Hippel (1988), Lead User Analyses for the Development of New Industrial Products, Management Science, 34, pp. 569-82.

18. CORNELIUS H., and Eric von Hippel (1992), From experience: developing new product concept via lead user method a case study in a "Low Tech Field", Journal of Product Innovation Management,9, 213-22I.

19.CHESBROUGH H., (2006) Open Innovation: A new Paradigm to Understanding Industrial Innovation, Open Innovation: Researching in New Paradigm: Oxford University Press, $\mathrm{CHI}$.

20. CHESBROUGH H., (2006) Open Innovation: A research agenda Open Innovation: Researching in New Paradigm: Oxford University Press, ChI4.

2I. FREEMAN, C. (199I), “'NNetworks of innovators: a synthesis of research issues", Research Policy, Vol. 20, No. 5, pp. 499. $5 \mid 4$.

22.VON HIPPEL, E. (1978), "Succesful industrial products from customer ideas", Journal of Marketing,Vol. 42 No. I, pp.39-49.

23. VON HIPPEL, E. (1988), The Sources of Innovation, Oxford University Press, New York.

24. NEALE, M.R. and Corkindale, D.R. (1998), "Co-developing products: involving customers earlier and more deeply", Long Range Planning, Vol. 3I No. 3, pp. 4I8-425

25. NAMEROFF T.J., Garant R.J., and Albert M.B (2004) Adoption of green chemistry: an analysis based on US patents,33, pp.959-974. 